\title{
A preliminary phylogenetic analysis of Pleurothallis sensu lato based upon nuclear and plastid sequences
}

\author{
M. Wilson*, C. Belle, A. Dang, P. Hannan, L. Kellogg, C. Kenyon, H. Low, A. \\ Mochizuki, A. Nguyen, N. Sheade, L. Shan, A. Shum, T. Stayton, C. Volz, B. \\ Vosburgh, H. Wellman \& M. Woolley \\ Biology Department, The Colorado College, Colorado Springs, CO 80903, USA \\ *Author for correspondence: mwilson@coloradocollege.edu
}

Morphological studies of Pleurothallis sensu lato by Luer and by Szlachetko have led them to propose several segregate genera, including Acronia, Ancipitia, Colombiana, Elongatia, Lindleyalis, Lalexia (for P. quadrifida), Mirandopsis, Rhynchopera, Talpinaria, and Zosterophyllanthos, leaving a much smaller group of species in Pleurothallis sensu stricto. In contrast, in molecular phylogenetic analyses by Pridgeon et al., species in the proposed taxa Ancipitia, Colombiana, Mirandopsis, Pleurothallis, Lindleyalis, Rhynchopera, and Talpinaria formed a clade, indicating Pleurothallis should be defined more broadly; however, the analyses included only 15 species in total from these groups. The current investigation includes several species from each of the proposed segregate genera (excluding Mirandopsis) as well as from each of the groups within Pleurothallis sensu stricto (Antenniferae, Longiracemosae, and Macrophyllae-Racemosae), for a total of $\sim 143$ ingroup species. Nuclear ITS and plastid matK markers have been sequenced for the majority of the species, and sequencing of 3' $y c f 1$ and $\operatorname{trn} L-F$ is underway. Preliminary analyses indicate that the species sampled from the taxa Acronia, Ancipitia, Colombiana, Lindleyalis, Lalexia, Pleurothallis, Rhynchopera, and Talpinaria do form a well-supported clade, as anticipated from the results of Pridgeon et al. However, from the proposed genus Elongatia, only the species Elongatia excelsa, E. macrophylla, E. restrepioides, and E. sijmii are included in the clade. Internally, there are well-supported distinct clades for species in the groups Ancipitia/Colombiana, Lalexia, Lindleyalis, Loddigesia, P. section MacrophyllaeFasciculatae (excluding Mesoamerican species in the P. excavata-group), and Rhynchopera. Pleurothallis section Pleurothallis subsection Acroniae is not monophyletic, its members distributed among three clades. 